\title{
DEVELOPMENT OF OPTIMAL TECHNOLOGY OF ALCOHOL EXTRACT CENTAURIUM ERYTHRAEA RAFN. HERB
}

\author{
Liliia STOIKO ${ }^{1 凶}$, Khrystyna KURYLO² \\ ${ }^{1}$ Department of Pharmacy Management, Economics and Technology, I. Horbachevsky Ternopil State \\ Medical University, Ternopil, Ukraine \\ ${ }^{2}$ Department of Pharmacology and Clinical Pharmacology, I. Horbachevsky Ternopil State Medical \\ University, Ternopil, Ukraine
}

Received 12 Sept 2018, Accepted 23 Oct 2018

https://doi.org/10.31688/ABMU.2018.53.4.06

\begin{abstract}
Introduction. Throughout the centuries, plants have been used not only as a source of nutrition, but also in the fight against diseases. The most interesting are medicinal plants being well tolerated by patients regardless of age. One of these plants is Centaurium erythraea Rafn. The aim of the study was to develop an optimal technology for obtaining an alcoholic extract with the highest content of biologically active substances: hydroxycinnamic acids, phenolic compounds.
\end{abstract}

Materials and methods. We have performed a study of the concentration of ethanol and multiplicity of dilution with the help of a symmetric rotary composite plan of the second order.

Results and discussion. The regression equations were adequate $-\mathrm{F}_{\exp } .<\mathrm{F}_{\mathrm{tab}}$. The nature of the influence of the studied factors was determined by the magnitude and signs of the coefficients from regression. To obtain the alcohol extract with the highest content of hydroxycinnamic acids and phenolic compounds, the concentration of ethanol should be $69 \%$, and the ratio of raw material to extractant should be 1 to 5 .

Conclusions. Further pharmacological studies showed the extract obtained reliability of its application for an increase in gastric acid secretion.

\section{Résumé}

Développement de la technologie optimale de l'extrait d'alcool de l'herbe Centaurium erythraea Rafn.

Introduction. Au cours des siècles, les plantes ont été utilisées non seulement comme source de nutrition, mais également dans la lutte contre les maladies. Les plus intéressantes sont les plantes médicinales bien tolérées par les patients, quel que soit leur âge. Une de ces plantes est Centaurium erythraea Rafn. Le but de l'étude était de développer une technologie optimale pour obtenir un extrait alcoolique avec la plus forte teneur en substances biologiquement actives: acides hydroxyconiques, composés phénoliques.

Matériels et méthodes. L'étude de la concentration en éthanol et la multiplicité de dilution ont été réalisées à l'aide d'un plan composite rotatif symétrique de second ordre.

Résultats et discussion. Les équations de régression étaient adéquates - Fexp. < Ftab. La nature de l'influence des facteurs étudiés a été déterminée par les amplitudes et les signes des coefficients de régression. Pour obtenir l'extrait alcoolique avec la teneur la plus élevée en acides hydroxycinnamiques et en composés phénoliques, la concentration en éthanol doit être de 
Keywords: hydroxycinnamic acids, phenolic compounds, ethanol concentration.
$69 \%$ et le rapport matière première / agent d'extraction doit être compris entre 1 et 5.

Conclusion. D'autres études pharmacologiques ont montré que l'extrait obtenu était fiable pour son application dans le but de l'augmentation de la sécrétion d'acide gastrique.

Mots-clés: acides hydroxycinnamiques, composés phénoliques, concentration en éthanol.

to thoroughly analyze the data of the experiment and obtain reliable results, which cannot always be achieved with the help of a subjective approach ${ }^{21}$. The stage of the planning of the experiment is especially crucial, when the influence of quantitative factors is studied. Quantitative factors are variables that can be quantified: measure, weight, etc ${ }^{22,23}$.

\section{Material AND MEthods}

Centaurium erythraea Rafn. herb was collected in Ukraine, on the outskirts of Zboriv (Ternopil region) during the flowering period in July 2013. The raw material was authenticated by Professor Dr. Svitlana Marchyshyn. A voucher specimen no. 133 is kept at the Department of Pharmacognosy and Medical Botany, I. Horbachevsky Ternopil State Medical University, Ukraine. The plant material was dried using conventional methods and then stored in paper bags in dry place?

When developing the optimal technology of alcohol extract of Centaurium erythraea Rafn. herb, the concentration of ethanol and the multiplicity of dilution were studied at five levels $s^{24,25}$.

The study of these two factors or two independent variables ${ }^{26}$ (ethanol concentration, the multiplicity of dilution) was carried out with the help of a symmetrical rotatable composite plan of the second order. The magnitude of "star shoulder" for this plan is $1.414^{27,28}$. The „star point" was found by multiplying the variation interval by the value of "star shoulder“. These values were added to the basic level, receiving the upper „star point" ("+ $\alpha$ ") and subtracted to obtain the lower „star point" ("- $\alpha$ “") 29 .

The results of the research were obtained from the regression analysis. We found the relationship between the studied factors and the content of hydroxycinnamic acids and phenolic compounds using the second order regression equation.

The second order model for two factors has the following form ${ }^{30,31}$;

$$
\mathrm{y}=\mathrm{b}_{0} \mathrm{x}_{0}+\mathrm{b}_{1} \mathrm{x}_{1}+\mathrm{b}_{2} \mathrm{x}_{2}+\mathrm{b}_{12} \mathrm{x}_{1} \mathrm{x}_{2}+\mathrm{b}_{11} \mathrm{x}_{1}{ }^{2}+\mathrm{b}_{22} \mathrm{x}_{2}{ }^{2}
$$


Table I. Quantitative factors and their levels, examined in the study of alcohol extracts derived from Centaurium erythraea Rafn. herb

\begin{tabular}{|c|c|c|c|c|c|c|}
\hline \multirow[b]{2}{*}{ Factor } & \multirow{2}{*}{$\begin{array}{c}\text { The } \\
\text { interval of } \\
\text { variation }\end{array}$} & \multicolumn{5}{|c|}{ Factor level } \\
\hline & & $\begin{array}{l}\text { Lower star } \\
\text { point } «-\alpha »\end{array}$ & $\begin{array}{c}\text { Bottom } \\
«-»\end{array}$ & $\begin{array}{c}\text { Main } \\
« 0 »\end{array}$ & $\begin{array}{l}\text { Top } \\
\text { «" }\end{array}$ & $\begin{array}{c}\text { Top star } \\
\text { point } «+\alpha »\end{array}$ \\
\hline $\mathrm{X}_{1}$ - concentration of ethanol, $\%$ & 10 & 41 & 45 & 55 & 65 & 69 \\
\hline $\begin{array}{c}\mathrm{X}_{2} \text { - the ratio of raw materials } \\
\text { and extractant }\end{array}$ & 2 & 5 & 6 & 8 & 10 & 11 \\
\hline
\end{tabular}

Table II. The matrix of experiment planning and the results of the study of alcohol extracts from Centaurium erythraea Rafn. herbs

\begin{tabular}{|c|c|c|c|c|c|}
\hline Series No. & $x_{1}$ & $x_{2}$ & $y_{1}$ & $y_{2}$ & Comment \\
\hline 1 & + & + & 9.57 & 13.98 & \multirow{4}{*}{ Full factorial experiment } \\
\hline 2 & - & + & 9.13 & 15.92 & \\
\hline 3 & + & - & 9.99 & 15.74 & \\
\hline 4 & - & - & 9.98 & 12.47 & \\
\hline 5 & +1.414 & 0 & 9.97 & 15.57 & \multirow{4}{*}{$\begin{array}{c}\text { Star } \\
\text { points }\end{array}$} \\
\hline 6 & -1.414 & 0 & 9.89 & 14.43 & \\
\hline 7 & 0 & +1.414 & 8.73 & 14.13 & \\
\hline 8 & 0 & -1.414 & 9.56 & 12.99 & \\
\hline 9 & 0 & 0 & 8.59 & 12.13 & \multirow{8}{*}{ Main level } \\
\hline 10 & 0 & 0 & 8.62 & 12.31 & \\
\hline 11 & 0 & 0 & 8.57 & 12.14 & \\
\hline 12 & 0 & 0 & 8.49 & 12.15 & \\
\hline 13 & 0 & 0 & 8.52 & 12.30 & \\
\hline 14 & 0 & 0 & 8.54 & 12.21 & \\
\hline 15 & 0 & 0 & 8.51 & 12.25 & \\
\hline 16 & 0 & 0 & 8.55 & 12.17 & \\
\hline
\end{tabular}

Comment: $\mathrm{y}_{1}$ - content of hydroxycinnamic acids, $\mathrm{mg} / \mathrm{ml} ; " \mathrm{y}_{2}$ - content of phenolic compounds, $\mathrm{mg} / \mathrm{ml}$.

Using the F-criterion, the statistical significance of the coefficients and the adequacy of the models were testified?

Among the indicated values of the concentration of ethanol $(41 \% v / v, 45 \% v / v, 55 \% v / v, 65 \% v / v, 69 \%$ $v / v)$ and the ratio of raw material: extractant $(1: 5,1: 6$, $1: 8,1: 10,1: 11)$, their optimal value was defined for obtaining the alcohol extract of Centaurium erythraea Rafn. herb with the highest content of hydroxycinnamic acids and phenolic compounds. The list of quantitative factors and five levels is given in Table $\mathrm{I}^{32,33}$.

To process the experimental data obtained, we used the method of mathematical planning of the experiment used by Visio and Statistica 6.0.

\section{Results AND DISCUSSION}

The regression equations were adequate $-\mathrm{F}_{\text {exp. }}$ $<\mathrm{F}_{\mathrm{tab}}$. The nature of the influence of the studied factors was determined by the magnitudes and signs of the coefficients from regression.
The matrix of experiment planning and the results of the study of alcohol extracts from Centaurium erythraea Rafn. herbs are presented in Table II.

The relationship between the investigated factors and the content of hydroxycinnamic acids is described by the following regression equation:

$\mathrm{y}_{1}=8.55+0.07 \mathrm{x}_{1}-0.31 \mathrm{x}_{2}+0.11 \mathrm{x}_{1} \mathrm{x}_{2}+0.72 \mathrm{x}_{1}^{2}+0.33 \mathrm{x}_{2}^{2}$.

We analyzed the magnitude of the coefficients and signs in front of them from the regression equation. However, in cases where the values of the coefficient of pair interaction $\left(0.11 \mathrm{x}_{1} \mathrm{x}_{2}\right)$ and quadratic coefficients $\left(0.72 \mathrm{x}_{1}{ }^{2}, 0.33 \mathrm{x}_{2}{ }^{2}\right)$ are greater than linear coefficients, it is appropriate to consider the analysis of the regression equation on the basis of graphic one-factor figures.

The influence of ethanol concentration and the ratio of raw material to extractant on the content of hydroxycinnamic acids of the alcohol extract of Centaurium erythraea Rafn. herb is depicted in Figures 1 and 2. 


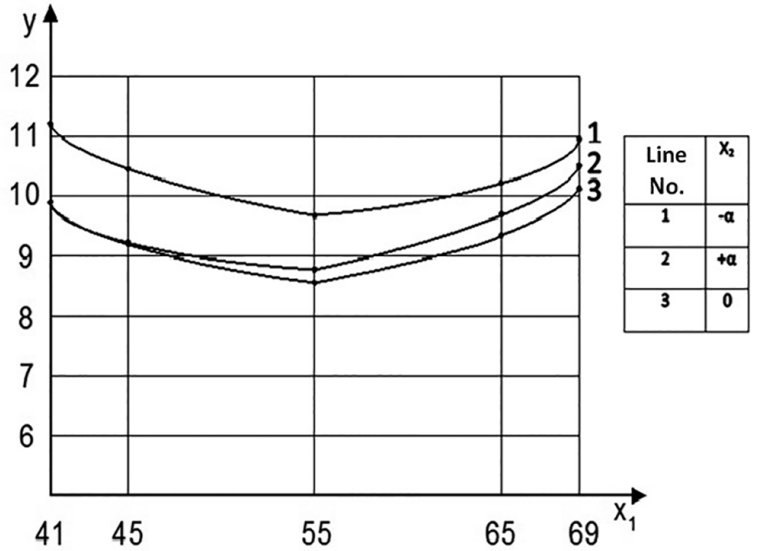

Figure 1. The influence of ethanol concentration on the extraction of hydroxycinnamic acids

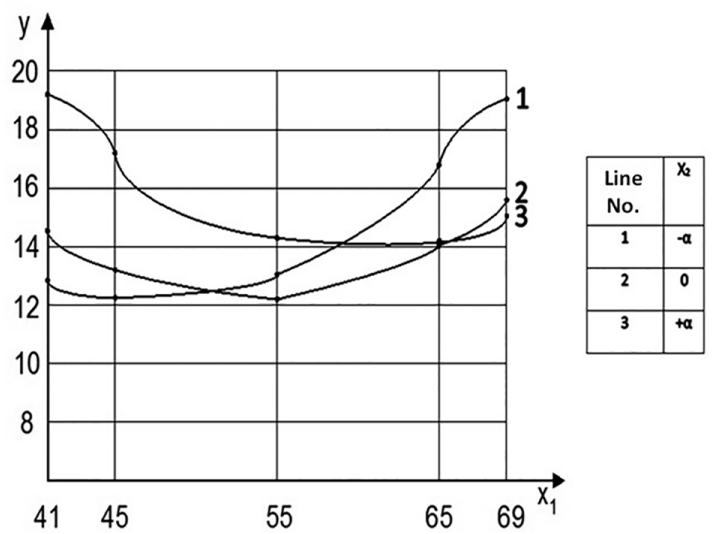

Figure 3. Effect of ethanol concentration on the extraction of phenolic compounds

Line no. $1\left(x_{2}=-\alpha\right)$ is the most promising for consideration, when the factor $\mathrm{x}_{2}$ is studied at the lower star point. As we can see from Figure 1, the content of hydroxycinnamic acids in alcoholic extract initially decreases from $11.21 \mathrm{mg} / \mathrm{mL}$ to $9.65 \mathrm{mg} / \mathrm{mL}$ with an increase in the concentration of ethanol from $41 \%$ to $55 \%$, and it increases to $10.97 \mathrm{mg} / \mathrm{mL}$ with further increase of ethanol concentration from $55 \%$ to $69 \%$.

Line no. $1\left(x_{2}=-\alpha\right)$ is the most promising for consideration, when the factor $\mathrm{x}_{2}$ is studied at the lower star point. As we can see from Figure 2, the content of hydroxycinnamic acids in alcoholic extract initially decreases from $10.97 \mathrm{mg} / \mathrm{mL}$ to $10.09 \mathrm{mg}$ / $\mathrm{mL}$ with an increase in the ratio of raw materials to the extractant from 1:5 to $1: 8$ and it rises to 10.53 $\mathrm{mg} / \mathrm{mL}$ with a further increase in the ratio of raw material to extractant from 1:8 to 1:11.

The relationship between the investigated factors and the content of phenolic compounds is described by the following regression equation:

$\mathrm{y}_{2}=12.21+0.37 \mathrm{x}_{1}+0.41 \mathrm{x}_{2}-1.30 \mathrm{x}_{1} \mathrm{x}_{2}+1.45 \mathrm{x}_{1}^{2}+0.73 \mathrm{x}_{2}^{2}$

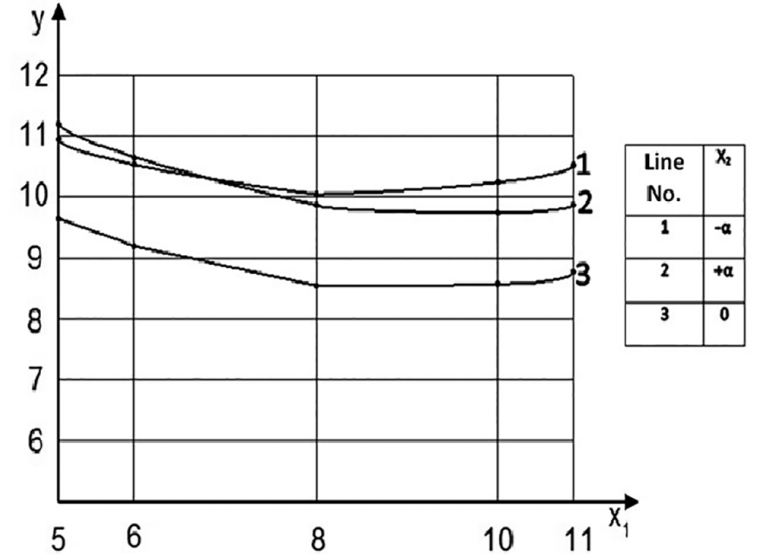

Figure 2. The effect of multiplicity of dilution on the extraction of hydroxycinnamic acids

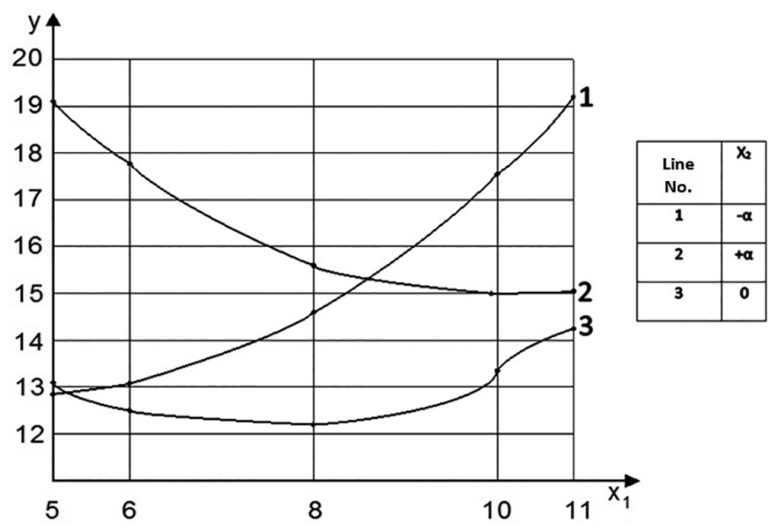

Figure 4. The impact of multiplicity of dilution on extraction of phenolic compounds

The impact of the values of ethanol concentration and multiplicity of dilution on the production of alcoholic extract from Centaurium erythraea Rafn. herbs with the highest content of phenolic compounds is presented in Figures 3 and 4.

Line no. $1\left(x_{2}=-\alpha\right)$ is the most promising for consideration, when the factor $\mathrm{x}_{2}$ is studied at the lower star point. As we can see from Figure 3, the content of phenolic compounds in alcoholic extract initially decreases from $12.87 \mathrm{mg} / \mathrm{mL}$ to $12.33 \mathrm{mg} / \mathrm{mL}$, with an increase in the concentration of ethanol from $41 \%$ to $45 \%$, and it increases to $19.11 \mathrm{mg} / \mathrm{mL}$ with a further increase in the concentration of ethanol from $45 \%$ to $69 \%$.

Line no. $1\left(x_{2}=-\alpha\right)$ is the most promising for consideration, when the factor $\mathrm{x}_{2}$ is studied at the lower star point. As we can see from Figure 4, the content of hydroxycinnamic acids in alcoholic extract increases from $12.87 \mathrm{mg} / \mathrm{ml}$ to $19.22 \mathrm{mg} / \mathrm{mL}$ with an increase in the ratio of raw materials to the extractant from 1:5 to 1:11. The nature of the lines in the 


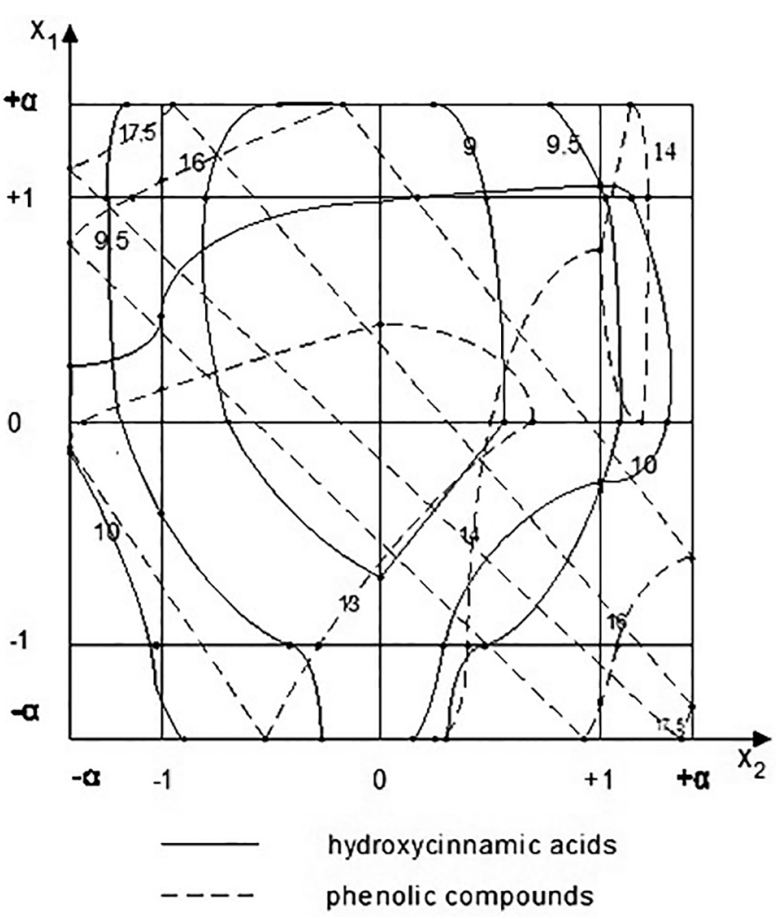

Figure 5. Lines of equal output of hydroxycinnamic acids and phenolic compounds in the coordinate system $\mathrm{x}_{1} \mathrm{x}_{2}$ according to the results of transformed regression equations

figure is determined not only by the magnitude of the linear coefficients but also by the pair and quadratic coefficients.

At the next stage of the analysis of second order regression equations, the optimal value of the factors (ethanol concentration, the ratio of raw materials to extractant) was found for obtaining the alcohol extract from Centaurium erythraea Rafn. herbs with the highest content of hydroxycinnamic acids and phenolic compounds. For this purpose, the regression equation is transformed into a canonical form. The canonical transformation consists of choosing a coordinate system, which greatly facilitates the geometric analysis of the equation.

In the study of two factors, we constructed the lines of equal yield of hydroxycinnamic acids and phenolic compounds in the coordinate system $\mathrm{x}_{1} \mathrm{x}_{2}$ (Figure 5).

As a result of the study, two optimizations were obtained:

- the first one is the content of hydroxycinnamic acids $\left(y_{1}=9.5\right)$, the factor $x_{1}$ is studied on the upper star point, the factor $\mathrm{x}_{2}$ - on the lower star point; the content of phenolic compounds $\left(y_{2}=17.5\right)$, the factor $x_{1}$ is studied on the upper star point, the factor $\mathrm{x}_{2}$ - on the lower star point.

- the second one is the content of hydroxycinnamic acids $\left(y_{1}=10\right)$, the factor $x_{1}$ is studied at the basic level, the factor $\mathrm{x}_{2}$ - on the upper star point; the content of phenolic compounds $\left(y_{2}=14\right)$, the factor $\mathrm{x}_{1}$ is studied on the main level, the factor $\mathrm{x}_{2}-$ on the upper star point.

The best option is the first one, when the factor $\mathrm{x}_{1}$ for $\mathrm{y}_{1}$ and $\mathrm{y}_{2}$ is studied at the top star point, and the factor $\mathrm{x}_{2}$ is at the lower star point.

\section{Conclusions}

To obtain the alcohol extract of Centaurium erythraea Rafn. herbs with the highest content of hydroxycinnamic acids and phenolic compounds, the concentration of ethanol should be $69 \%$, and the ratio of raw material to extractant should be 1 to 5 . Further pharmacological studies of the resulting extract showed an evidence of the relevance of its use in order to increase the secretion of gastric juice.

\section{Compliance with Ethics Requirements:}

„The authors declare no conflict of interest regarding this article"

"No funding for this study"

\section{References}

1. Shakya AK. Medicinal plants: Future source of new drugs. International Journal of Herbal Medicine 2016;4(4): 59-64.

2. Kyslychenko VS, Zhuravel IO, Marchyshyn SM, Minarchenko VM, Khvorost OP. Pharmacognosy. 1st ed. Kharkiv: Golden Pages, 2015: 8-10.

3. Nasri H, Bahmani M, Shahinfard N, et al. Medicinal plants for the treatment of acne vulgaris: a review of recent evidences. Jundishapur Journal of Microbiology 2015; 8(11):e25580.

4. European Pharmacopoeia, 9th edition. Strasbourg: European Department for the Quality of Medicines, 2017: 1310.

5. State Pharmacopoeia of Ukraine. 2nd edition. Ukraine: Ukrainian Scientific Pharmacopoeial Center for the Quality of Medicines, 2016: 164-6.

6. Willoughby MJ, Mills S. British Herbal Pharmacopoeia, 4th edition. U.K.: British Herbal Medicine Association, 1996: $57-8$.

7. Stoiko L, Dakhym I, Pokotylo O, Marchyshyn S. Polysaccharides in Centaurium erythraea Rafn. International Journal of Research in Ayurveda and Pharmacy 2017;8(2): 252255.

8. Stefkov G, Miova B, Dinevska-Kjovkarovska S, et al. Chemical characterization of Centaurium erythrea L. and its effects on carbohydrate and lipid metabolism in experimental diabetes. Journal of Ethnopharmacology 2014;152(1): 71-77.

9. Berkan T, Ustunes L, Lermioglu F, Ozer A. Antiinflammatory, analgesic, and antipyretic effects of an aqueous extract of Erythraea centaurium. Planta Medica 1991;57: 34-37.

10. Duke JA, Bogenschutz-Godwin MJ, Cellier J, Duke P-AK. Handbook of medicinal herbs, 2nd edition. London. New York. Washington: CRC Press, 2002: 172-3. 
11. Barnes J, Anderson LA, Phillipson JD. Herbal Medicines, 3rd edition. London. Chicago: Pharmaceutical Press 2007: $149-50$.

12. Marchyshyn SM, Stoiko LI. Definition of Phenolic compounds in herbs of Centaurium erythraea Rafn. by HPLC. Pharmaceutical review 2014;1(29): 15-17.

13. Marchyshyn SM, Stoiko LI. Volatile compounds of Centaurium erythraea Rafn. and Gentiana cruciata L. Phytotherapy. Review 2016;3: 45-48.

14. Marchyshyn SM, Stoiko LI. The composition of lipophilic fraction from the herbs of Centaurium erythraea Rafn. Ukrainian Biopharmaceutical Journal 2015;1: 65-68.

15. Bionorica. Canephron ${ }^{\circledR} \mathrm{N}$ - Herbal support for bladder infection. http://english.bionorica.de (Accessed on May 23, 2018).

16. Universal reference book for medicines. Original Bigger Bittner Balsam (Original Grosser Bittner Balsam). http:// lekarstwo.ru (Accessed on May 23, 2018).

17. Vital-kraeuter.ch. Löwenzahn, Edelweiss, Tausendgüldenkraut und Cholin Saft. https://vital-kraeuter.ch (Accessed on May 23, 2018).

18. Soin et Nature. DIACURE metabolic disorders 60 capsules. https://www.soin-et-nature.com (Accessed on May 23, 2018).

19. Leros. Stomaran. http://www.leros.cz (Accessed on May 23, 2018).

20. Różycki C, Synoradzki L. Teaching the experimental design. Lecture and exercises. Przemyst chemiczny 2003;8-9:1342-4.

21. Bouziani T, Benmounah A, Bederina M. Statistical modelling for effect of mix-parameters on properties of high-flowing sand-concrete. Journal of Central South University 2012;19: 2966-75.

22. Kucherenko LI. Development of optimal composition and technology of cardiotril tablets by direct compression method. Pharmaceutical review 2014;1(29): 67-71.

23. Hroshovyi TA, Marcenyuk VP, Kucherenko LI, Vronska LV, Gureyeva SM. Mathematical planning of the experiment in conducting scientific research in pharmacy. Ternopil: TSMU, 2008: 304-309.
24. Patwari MAU, Nurul Amin AKM, Faris WF. Prediction of tangential cutting force in end milling of medium carbon steel by coupling design of experiment and response surface methodology. Journal of Mechanical Engineering 2009;40(2): 95-103.

25. Patel V, Bisoniya TS. Experimental investigation of effect of machining parameters on surface roughness in roller burnishing process. International Journal For Technological Research In Engineering 2015;9: 2201-4.

26. Popa A, Bucevschi A, Pustianu M, Manea LR, Sandu I. Mathematic model of the spinning process of a wool yarn. Materiale Plastice 2016;2(53): 316-20.

27. Nikolenko I, Karimov E. Increase of reverse water supply systems effectiveness in production of construction materials. TEKA. Commission of Motorization and Energetics In Agriculture 2014;14(4): 105-112.

28. Tang LV, Bulgakov B, Bazhenova S, et al. Effect of Rice Husk Ash and Fly Ash on the workability of concrete mixture in the High-Rise Construction. Engineering systems and building materials 2018; 33:13. Paper presented at: E3S Web of Conferences, March 06, 2018, Samara, Russia.

29. Denys AI. Optimization of composition and technology of tablets based on the extract of Chinese Poplar leaf. Pharmaceutical Review 2014;1(29): 62-66.

30. Minka C, Omer SE. Modeling and optimization of force fracture of plywood under the action of bending forces. Wood, Design $\mathcal{E}$ Technology 2014;3(1): 49-58.

31. Iștoc IV, Pustianu M, Dochia AM, Sîrghie C, Popescu A. Study regarding the optimization of the bioscouring treatment with ultrasound on $100 \%$ cotton materials. Industria Textila 2014;2: 70-4.

32. Patel A, Patel D, Banker K. Effect evaluation of roller burnishing process on surface roughness of $6061 \mathrm{~T} 6 \mathrm{Al}$ alloy using response surface methodology. International Journal for Scientific Research $\mathcal{E}$ Development 2014;8: 142-5.

33. Anayet Md, Patwari U, Amin AKMN, Faris W. Mathematical model for the prediction of chip serration frequency in end milling of steel AISI1020. Annals of Faculty Engineering Hunedoara - International Journal of Engineering 2009;7(1): 89-96. 